\title{
Polymer Films BaSed on Cellulose Containing Silver NANOPARTICLES AND VITAMIN C
}

\author{
Karolína Borůvková ${ }^{1}$; Jakub Wiener ${ }^{2}$ \\ Technical University of Liberec, Faculty of Textile Engineering, \\ Department of Material Engineering, Studentská 2, 46117 Liberec, Czech Republic \\ e-mail: ${ }^{1}$ karolina.boruvkova@ tul.cz; ${ }^{2}$ jakub.wiener@tul.cz
}

\begin{abstract}
The preparation of films containing silver nanoparticles and vitamin $\mathrm{C}$ in the polymer matrix is presented in this work. Such films are capable of absorbing excessive amounts of water. In this case, $-\mathrm{COOH}$ groups in the $\mathrm{CMC}$ and ascorbic acid function as the reducing agents. The films prepared with silver nanoparticles and vitamins $C$ are investigated by using the scanning electron microscope. Samples are also evaluated for their antioxidant and antimicrobial activity. The product of the presented technology is non-toxic with a high potential in biological applications.
\end{abstract}

\section{Introduction}

Carboxymethyl cellulose (CMC) is prepared in two steps, the first of which is based on the preparation of alkali cellulose by reaction of cellulose with sodium hydroxide. This reaction is followed by the carboxymethylation with a monochloroacetic acid or its sodium salt. The aim is to convert the hydroxyl groups in carboxymethyl groups. [1] Various properties of CMC depend on three factors namely: the molecular weight of the polymer, the average of carboxyl content per anhydroglucose unit and the distribution of carboxyl substitutes along the polymer chain. The most important characteristic is the viscosity of CMC structure and flocculation. [2] CMC is nontoxic, biodegradable and water-soluble macromolecular material with good biocompatibility and stable physical properties. These properties are used in technical and medical applications, such as a tool to minimize blood loss and prevent postoperative adhesion. [3, 4] CMC is biocompatible macromolecule, which has been used for drug delivery systems in lots of studies with the aim of controlled release of drugs, such as microgel matrix for a new type of patch. Due to its adhesive properties, CMC can also be used as a bioadhesive material (mucoadhesive polymer for nasal and oral drug delivery systems). [5]

Antioxidants are phytochemicals, vitamins and other substances. It is already known that antioxidants are substances that can protect the human body from the adverse effects of some reactive compounds or free radicals. [6] To determine the antioxidant activity there are a number of analytical methods. In the field of chemical analysis and biological evaluation of antioxidant characteristics in recent years numerous methods have been developed. They are principally different and their modifications are gradually developed. [7] Most of the methods used are based on the elimination of radicals, such as DPPH method, TEAC, ORAC, PCL or assessment redox properties (FRAP), voltammetry, high- performance liquid chromatography. When evaluating the antioxidant activity, effects of substances with different chemical nature are assessed with different reaction mechanisms. These methods are based on different principles. Vitamin $\mathrm{C}$ has antioxidant properties, which are essential in the formation of collagen and cartilage (in combination with calcium), higher doses improve healing of any wounds, burns, fractures and joint pain. Vitamin $\mathrm{C}$ is found in all body tissues, where it helps strengthen cell walls and capillaries. 
Silver is a metallic element with the chemical symbol Ag and atomic number 47 . There are numerous applications where silver is important. It is a known fact that the smaller the particle size (nanometers), the better one can change the chemical, electrical, mechanical and optical properties. [8]

Highly dispersed silver nanoparticles are used as catalysts, pigments, tinted glasses and ceramics, antimicrobial materials, in Raman spectroscopy, electronics, etc. There are several methods to prepare the silver nanoparticles, which have previously been described, including a chemical reduction of silver ions in aqueous solutions (with or without stabilizers), thermal decomposition in organic solvents, photo reduction and chemical reduction. [9] The aim of this study was to develop a biocompatible polymeric film, connecting the antimicrobial and antioxidant activity. The resulting product is intended for medical applications such as wound healing.

\section{$1 \quad$ Experimental part}

\subsection{Materials and chemical used}

The parameters of the used materials and the prepared solutions are listed in Table 1 and 2 .

Tab. 1: $C M C$

Source: Own

\begin{tabular}{|l|c|c|}
\hline Sample & Concentration & Degree of substitution \\
\hline powder form & $20 \mathrm{~g} / 1$ & 0.700 \\
\hline dissolved textile material & $17 \mathrm{~g} / 1$ & 0.251 \\
\hline
\end{tabular}

Chemicals (Lachema Brno) - Ascorbic acid $\left(\mathrm{C}_{6} \mathrm{H}_{8} \mathrm{O}_{6}\right)$, Silver nitrate $\left(\mathrm{AgNO}_{3}\right)-(\mathrm{Czech}$ technical norm ČSN 684421), Glycerin $\left(\mathrm{C}_{3} \mathrm{H}_{8} \mathrm{O}_{3}\right)$

Tab. 2: Composition of each solution (50ml)

\begin{tabular}{|c|l|c|c|c|c|}
\hline Sample & CMC & $\begin{array}{c}\text { Amount of CMC } \\
{[\mathbf{W} \text { \%] }}\end{array}$ & $\begin{array}{c}\text { Silver nitrate } \\
{[\mathbf{W} \text { \%] }}\end{array}$ & $\begin{array}{c}\text { Ascorbic acid } \\
\text { [W\%] }\end{array}$ & $\begin{array}{c}\text { Glycerin } \\
\text { [W\%] }\end{array}$ \\
\hline $\mathbf{1}$ & powder form & 2 & 0 & 3 & 2 \\
\hline $\mathbf{2}$ & dissolved textile mat. & 1.7 & 0 & 3 & 2 \\
\hline $\mathbf{3}$ & powder form & 2 & 0.03 & 0.75 & 2 \\
\hline $\mathbf{4}$ & dissolved textile mat. & 1.7 & 0.03 & 0.75 & 2 \\
\hline $\mathbf{5}$ & powder form & 2 & 0.06 & 1 & 2 \\
\hline $\mathbf{6}$ & dissolved textile mat. & 1.7 & 0.06 & 1 & 2 \\
\hline
\end{tabular}

Source: Own

\subsection{Test methods}

\subsubsection{Antimicrobial activity}

\section{Tergitol 7 Agar Base (HiMedia)}

This method assesses the cultural characteristics observed after incubation at $37{ }^{\circ} \mathrm{C}$ for 24 hours. Yellow color means well blooming of Escherichia coli ATCC 25922. It was also evaluated by the size of inhibition zone (halo zone). The composition of the Tergitol agar is shown in Table 3. 
Tab. 3: The composition of the agar Tergitol 7

Source: http://himedialabs.com/TD/M850.pdf

\begin{tabular}{|l|r|}
\hline Tergitol 7 Agar Base \\
\hline composition & \multicolumn{1}{|c|}{ g/ l } \\
\hline Proteose pepton & 5.000 \\
\hline Yeast extract & 3.000 \\
\hline Lactose & 10.000 \\
\hline Sodium heptadecyl sulphate(Tergitol 7) & 0.100 \\
\hline Bromthymol blue & 0.025 \\
\hline Agar & 15.000 \\
\hline final pH $\left(25^{\circ} \mathrm{C}\right)$ & $6.9 \pm 0.2$ \\
\hline
\end{tabular}

\section{Columbia Blood agar with $5 \%$ of sheep blood (Bio-Rad Praha)}

The blood agar is highly nutritious universal medium for the isolation and cultivation of fastidious and undemanding microorganisms. The composition of the blood agar is shown in Table 4.

Tab. 4: The composition of the Columbia blood agar

\begin{tabular}{|l|c|}
\hline Columbia Agar with 5\% Sheep Blood \\
\hline composition & g / l of pure water \\
\hline Pancreatic Digest of Casein & 12.00 \\
\hline Peptic Digest of Animal Tissue & 5.00 \\
\hline Yeast Extract & 3.00 \\
\hline Beef Extract & 3.00 \\
\hline Corn Starch & 1.00 \\
\hline Sodium Chloride & 5.00 \\
\hline Agar & 13.50 \\
\hline Sheep Blood, Defibrinated & $5 \%$ \\
\hline pH & $7.3 \pm 0.2$ \\
\hline
\end{tabular}

Source: http://www.bd.com/resource.aspx?IDX=8968

The tested bacterial strains: Escherichia coli (CCM 2024) and Staphylococcus aureus (CCM 229) with concentration of $105 \mathrm{CFU} / \mathrm{ml}$ are used in this method. Test methods are AATCC147 and AATCC100.

- AATCC 147 - $1 \mathrm{ml}$ of bacterial inoculum with a concentration of $105 \mathrm{CFU} / \mathrm{ml}$ was inoculated with a blood agar on the petri dish. Samples with size of $2 \times 2-3 \mathrm{~cm}$ were placed at the center of dishes. These dishes were then incubated at $37{ }^{\circ} \mathrm{C}$ for 24 hours and subsequently evaluated by the size of the halo zone.

- AATCC 100 - Bacterial strains named Escherichia coli and Staphylococcus aureus were used. The initial concentration of the bacterial mixture was $105 \mathrm{CFU} / \mathrm{ml}$. Samples were placed in containers and they were inoculated with $10 \mu 1$ of bacterial suspension. After that they were incubated for 24 hours at $37^{\circ} \mathrm{C}$. The next day samples were diluted with $10 \mathrm{ml}$ of saline and they were vortexed. $1 \mathrm{ml}$ of this solution was inoculated on dishes with blood agar which was then incubated for $48 \mathrm{~h}$ at $37{ }^{\circ} \mathrm{C}$.

\subsubsection{Antioxidant properties}

The test method using stable 2, 2-diphenyl-1-pikrylhydrazyled radical (DPPH) is commonly used for determining the antiradical activity of pure synthetic antioxidants, isolated natural 
products, plant extracts and food. The presence of antioxidants with antiradical activity causes a reduction of colour $(\lambda \max =517 \mathrm{~nm})$ stable radical DPPH to the colourless neutral molecule. The speed and range of discoloration (absorbance decrease) are proportional to the antioxidant (antiradical) efficiency of the analyzed substances (extract). $2 \mathrm{ml}$ of this testimonial radical was added to $50 \mathrm{ml}$ of the sample. The decrease in absorbance from the original value of 1.6 was observed using a Helios Epsilon spectrophotometer.

\subsubsection{SEM analysis}

The SEM is routinely used to generate high-resolution images of shapes of objects. Accelerated electrons in an SEM carry significant amounts of kinetic energy, and this energy is dissipated as a variety of signals produced by electron-sample interactions when the incident electrons are decelerated in the solid sample. These signals include secondary electrons (that produce SEM images), backscattered electrons (BSE), diffracted backscattered electrons (EBSD that are used to determine crystal structures and orientations of minerals), photons (characteristic X-rays that are used for the elemental analysis and continuum X-rays), visible light (cathodoluminescence-CL), and heat. To analyze non-conductive samples, it is necessary to make a conductive layer on their surface. To do this, common techniques are sputtering metals or their evaporation (generally gold or platinum).

\section{$2 \quad$ Results and discussion}

\subsection{Antibacterial activity test}

\subsubsection{Tergitol 7 Agar Base - samples tested for Ecoli}

The results of the inhibitory effect of all samples are shown in Table 5. The picture of the sample No. 2 after incubation is shown in Figure 1.

Tab. 5: The results of antibacterial activity of samples using the agar Tergitol 7

\begin{tabular}{|c|l|}
\hline Sample & Escherichia coli $\left(\mathbf{1 0}^{\mathbf{3}} \mathbf{C F U} / \mathbf{~ m l}\right)$ \\
\hline $\mathbf{1}$ & without halo zone \\
\hline $\mathbf{2}$ & halo zone $2 \mathrm{~mm}$ \\
\hline $\mathbf{3}$ & without halo zone \\
\hline $\mathbf{4}$ & without halo zone \\
\hline $\mathbf{5}$ & halo zone $4 \mathrm{~mm}$ \\
\hline $\mathbf{6}$ & halo zone $4 \mathrm{~mm}$ \\
\hline
\end{tabular}

Source: Own

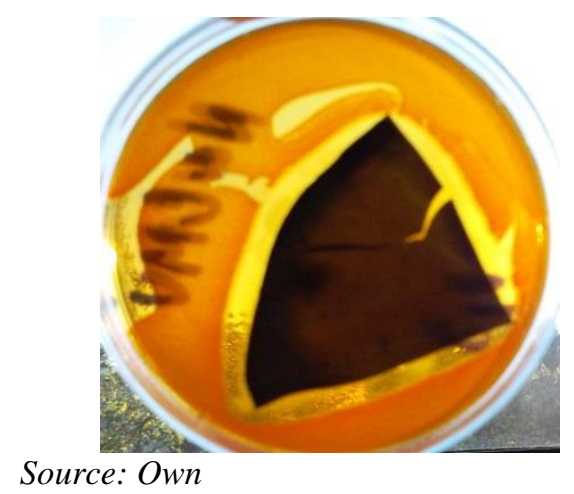

Fig. 1: Sample No. 2

\subsubsection{Blood agar}

Some results of the inhibitory effect are shown in Figures 2 and 3. 
Tab. 6: The results of antibacterial activity test AATCC 147

\begin{tabular}{|c|c|c|}
\hline Sample & $\begin{array}{l}\text { Staphylococcus aureus } \\
\qquad\left(10^{5} \mathrm{CFU} / \mathrm{ml}\right)\end{array}$ & $\begin{array}{l}\text { Escherichia coli } \\
\left(10^{5} \mathrm{CFU} / \mathrm{ml}\right)\end{array}$ \\
\hline 1 & $\begin{array}{l}\text { No inhibitory effect, was observed } \\
\text { haemolysis diameter } 1.8 \mathrm{~cm}\end{array}$ & $\begin{array}{l}\text { No inhibitory effect, was observed } \\
\text { haemolysis diameter } 1.5 \mathrm{~cm}\end{array}$ \\
\hline 2 & $\begin{array}{l}\text { No inhibitory effect, was observed } \\
\text { haemolysis diameter } 2.2 \mathrm{~cm}\end{array}$ & $\begin{array}{l}\text { No inhibitory effect, was observed } \\
\text { haemolysis diameter } 2.1 \mathrm{~cm}\end{array}$ \\
\hline 3 & $\begin{array}{l}\text { No inhibitory effect, was observed } \\
\text { haemolysis diameter } 0.7 \mathrm{~cm}\end{array}$ & $\begin{array}{l}\text { No inhibitory effect, was observed } \\
\text { haemolysis diameter } 0.6 \mathrm{~cm}\end{array}$ \\
\hline 4 & $\begin{array}{l}\text { No inhibitory effect, was observed } \\
\text { haemolysis diameter } 0.2 \mathrm{~cm}\end{array}$ & $\begin{array}{l}\text { No inhibitory effect, was obse } \\
\text { haemolysis diameter } 0.7 \mathrm{~cm}\end{array}$ \\
\hline 5 & $\begin{array}{l}\text { No inhibitory effect, was observed } \\
\text { haemolysis diameter } 0.7 \mathrm{~cm}\end{array}$ & $\begin{array}{l}\text { A hint of inhibition, was obse } \\
\text { hemolysis diameter } 0.6 \mathrm{~cm}\end{array}$ \\
\hline 6 & $\begin{array}{l}\text { Inhibition zone of } 0.4 \mathrm{~cm} \text {, was observed } \\
\text { hemolysis diameter } 0.9 \mathrm{~cm}\end{array}$ & $\begin{array}{l}\text { Inhibition zone of } 0.1 \mathrm{~cm}, \text { was } \\
\text { observed hemolysis diameter } 0.7 \mathrm{~cm}\end{array}$ \\
\hline
\end{tabular}

Source: Own

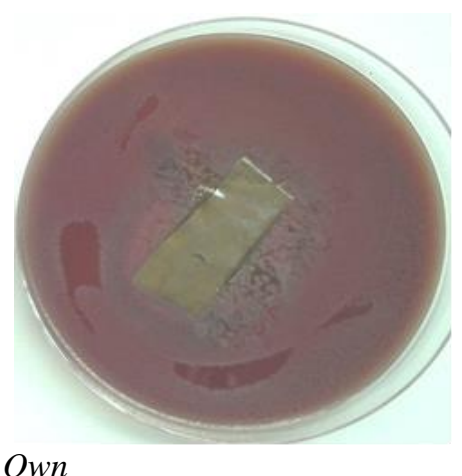

Source: Own

Fig. 2: Sample No. 5 - Escherichia coli

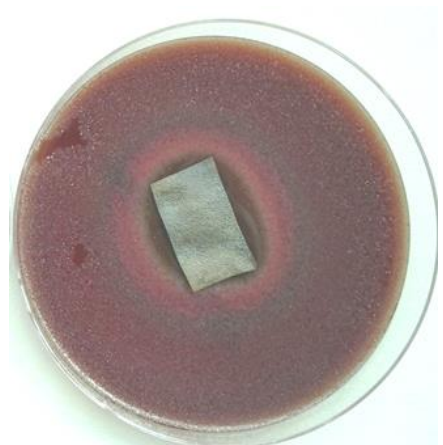

Source: Own

Fig. 3: Sample No. 6 - Staphylococcus aureus

Tab. 7: The results of the method AATCC 100

Source: Own

\begin{tabular}{|c|c|c|}
\hline Sample & $\begin{array}{c}\text { Staphylococcus aureus } \\
\left(10^{5} \mathrm{CFU} / \mathrm{mL}\right)\end{array}$ & $\begin{array}{l}\text { Escherichia coli } \\
\left(10^{5} \text { CFU / mL }\right)\end{array}$ \\
\hline 1 & 4 molds, 150 bacteria & 15 molds, compact seed of bacteria \\
\hline 2 & 50 bacteria & 60 bacteria \\
\hline 3 & 120 bacteria & 45 bacteria \\
\hline 4 & 85 bacteria & 35 bacteria \\
\hline 5 & 5 molds, 120 bacteria & 2 molds, 150 bacteria \\
\hline 6 & 150 bacteria & 22 bacteria \\
\hline
\end{tabular}


Source: Own

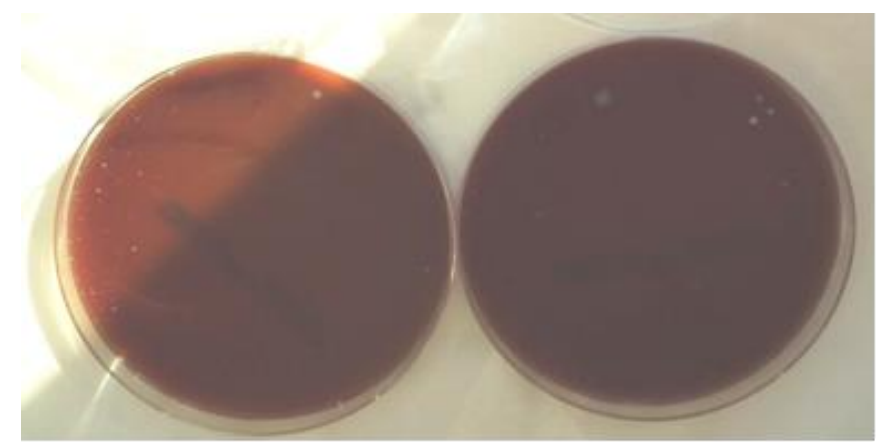

Fig. 4: Sample No. 2 - (left)Escherichia coli, (right)Staphylococcus aureus

The contact qualitative method AATCC147 shows "the best antibacterial effect" for sample No. 6 (both the tested pathogenic bacterial strains). Other samples show especially hemolysis (hemolysis is the breakdown of erythrocytes), which is a part of the blood agar. It is caused by enzymes that produce bacteria. Molds and bacteria appeared in the quantitative method AATCC100. In the case of E. coli, the best result was observed in sample No. 6 (bacterial inhibition of 99.95\%). In the case of Staphylococcus aureus, sample No. 2 (bacterial inhibition of 99.97\%) has the best results, as can be seen in Figure 4.

\subsection{Antioxidant properties}

Samples No. 1 and 2 were too strong, so they had to be dissolved in $500 \mathrm{ml}$ of distilled water instead of $50 \mathrm{ml}$. In fact, these two samples are 10 times stronger than the other samples tested. The higher decrease of absorbance means a higher antioxidant activity. The measured values of decrease of absorbance are shown in Table 8.

Tab. 8: The results of antioxidant activity

\begin{tabular}{|c|c|c|}
\hline Amount of sample & Sample & A decrease of absorbance \\
\hline $0.3 \mathrm{~g}$ & $\mathbf{1}$ & 0.470 \\
\hline & $\mathbf{2}$ & 0.126 \\
\hline $0.3 \mathrm{~g}$ & $\mathbf{3}$ & 0.875 \\
\hline & $\mathbf{4}$ & 0.590 \\
\hline & $\mathbf{5}$ & 0.090 \\
\hline & $\mathbf{6}$ & 0.062 \\
\hline
\end{tabular}

Source: Own

\subsection{SEM}

Each sample was covered with gold before scanning. Images with a magnification of $2500 \mathrm{x}$ are shown in Figures 5-11.

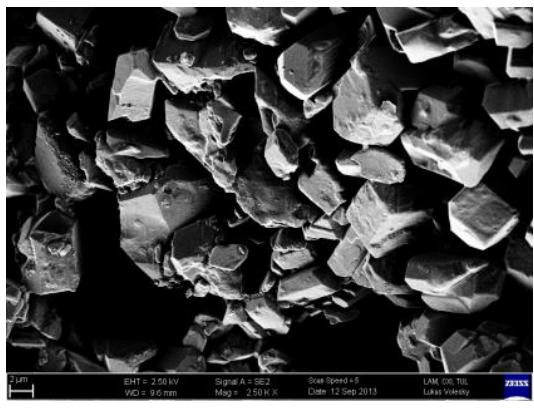

Source: Own

Fig. 5: Sample No. 1

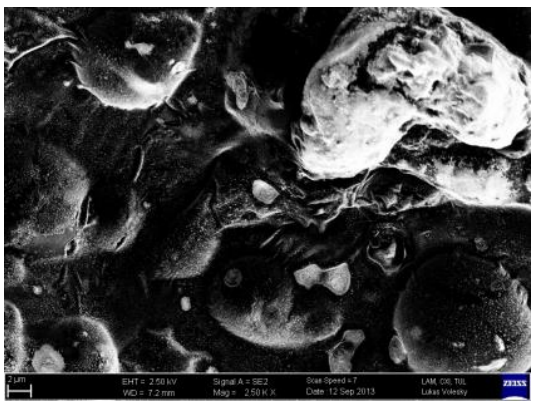

Source: Own

Fig. 6: Sample No. 2 


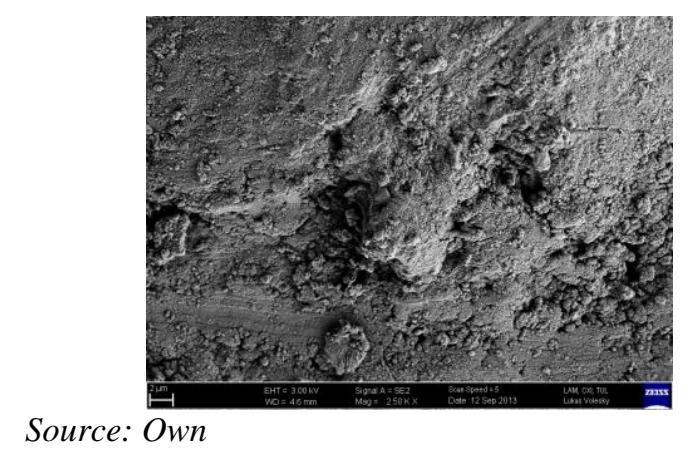

Fig. 7: Sample No. 3

Source: Own

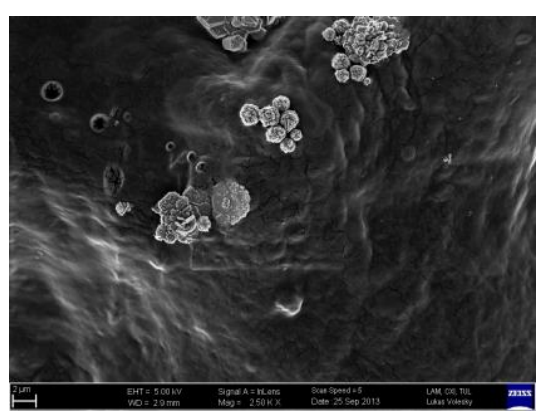

Fig. 9: Sample No. 5

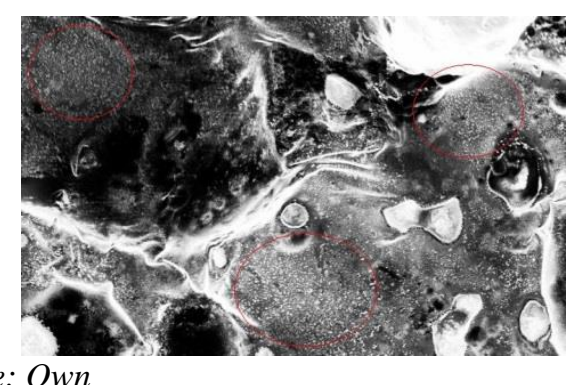

Fig. 11: Sample No. 3 - silver nanoparticles

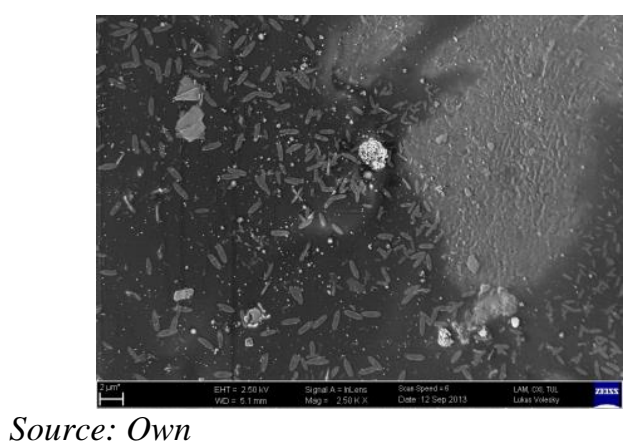

Fig. 8: Sample No. 4

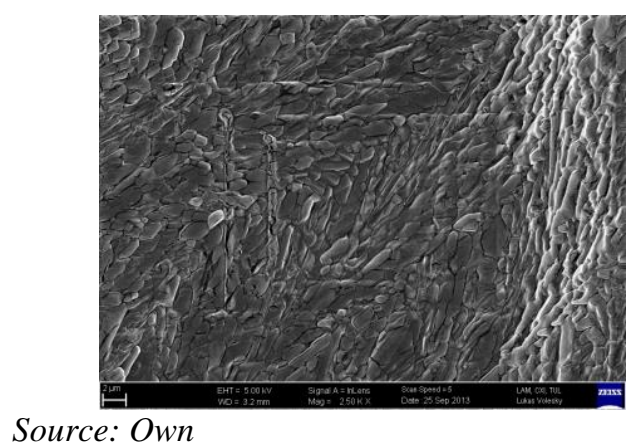

Fig. 10: Sample No. 6

From Figures 5 and 6, it is evident that films not containing silver have larger particles in their structure. Vitamin $\mathrm{C}$ is crystallized on the surface of the films. The Figure 11 shows the presence of silver nanoparticles.

\section{Conclusion}

In this work, 6 samples of films were prepared and evaluated with a different amount of silver and vitamin $\mathrm{C}$ content. The aim of this study was to develop a material that would integrate an antioxidant with an antimicrobial activity while also being highly absorbent. Samples No. 1 and 2 showed the best results in the case of the antioxidant properties. On the other hand, samples No. 5 and 6 that contained the highest amount of silver, showed the best results of antibacterial activity. Sample No. 2, which did not contain silver, showed almost a $100 \%$ inhibition effect against Staphylococus aureus. After the initial investigation, it is clear that it would be interesting to continue with observations of the changes in the surface structure and selected properties depending on different concentrations or amounts of added substances.

\section{Acknowledgements}

This paper is supported by SGS 48008 and TAČR ALFA TA01010244 (HMEDMAT), Czech Republic. 


\section{Literature}

[1] HEINZE, T.; PFEIFFER, K.: Studies on the synthesis and characterization of carboxymethylcellulose, Angewandte Makromolekulare Chemie. 266, 37-45 (1999).

[2] BISWAL, D.R.; SINGH, R.P.: Characterisation of carboxymethyl cellulose and polyacrylamide graft copolymer, Carbohydrate Polymers. 57, 2004.

[3] GORGEIVA, S.; KOKOL, V.: Synthesis and application of new temperature-responsive hydrogels based on carboxymethyl and hydroxyethyl cellulose derivatives for the functional finishing of cotton knitwear. Carbohydrate polymers. 85, 664-673 (2011).

[4] ADEL, A. M.; ABOU-YOUSSEF, H.; El-GENDY, A. A.; NADA, A. M.: Carboxymethylated Cellulose Hydrogel; Sorption Behavior and Characterization. Nature and science. 8, 2010.

[5] BUTUN, S.; GULINE, F.; ERDUGAN, H.; SAHINER, N.: One- step fabrication of biocompatible carboxymethyl cellulose polymeric particles for drug delivery systems. Carbohydrate Polymers. 86, 636-643 (2011).

[6] MITTLER, R.: Oxidative stress, antioxidants and stress tolerance. Trends in Plant Science. 7(9), 405 - 410 (2002).

[7] ROY, M. K.; et al.: ORAC and DPPH assay comparison to assess antioxidant capacity of tea infusions: Relationship between total polyphenol and individual catechin content. International Journal of Food Sciences and Nutrition. 61(2), 109-124 (2010).

[8] MARZAN, L.; LADO-TOURINO, I.: Reduction and Stabilization of Silver Nanoparticles in Ethanol by Nonionic Surfactants, Langmuir. 12, 3585-3589 (1996).

[9] OZIN, G. A.; ARSENAULT, A. C.: Nanochemistry, A Chemical Approach to Nanomaterials $2^{\text {nd }} e d$., RSC Publishing: Cambridge, United Kingdom, 2006.

Ing. Karolína Borůvková; prof. Ing. Jakub Wiener, Ph.D. 


\section{POLYMERNÍ FILMY NA BÁZI CELULÓZY S OBSAHEM NANOČÁSTIC STŘÍBRA}

\section{A VITAMÍNU C}

V této studii je prezentována př́íprava filmů, které obsahují nanočástice stř́ibra popř. vitamín C v polymerní matrici, která je schopna absorbovat extrémní množství vody. Redukčními činidly v tomto př́padě byly $\mathrm{COOH}$ skupiny v $\mathrm{CMC}$ a kyselina askorbová. Připravené filmy s nanočásticemi stříbra či vitamínem $\mathrm{C}$ jsou zkoumány pomocí skenovací elektronové mikroskopie. Dále je měřena jejich antioxidační a antimikrobiální aktivita. Produkt prezentované technologie je netoxický, s vysokým potenciálem v biologických aplikacích.

\section{POLYMERFILME AUF ZELLULOSEBASIS MIT SILBERNANOPARTIKELN UND VITAMIN C}

In dieser Studie wird die Aufbereitung von Filmen mit Silber-Nanopartikeln und Vitamin C in der Polymermatrix vorgestellt, die in der Lage ist, große Mengen an Wasser zu absorbieren. Reduktionsmittel waren in diesem Fall die COOH-Gruppen in der $\mathrm{CMC}$ und Ascorbinsäure. Die mit Silber-Nanopartikeln und Vitamin C bearbeiteten Filme werden mit Hilfe der Rasterelektronenmikroskopie untersucht. Des Weiteren wird ihre antioxidative und antimikrobielle Aktivität gemessen. Das Produkt der vorgestellten Technologie ist ungiftig und bietet daher ein hohes Potential bei biologischen Anwendungen.

\section{FILMY POLIMEROWE NA BAZIE CELULOZY ZAWIERAJĄCEJ NANOCZĄSTECZKI SREBRA I WITAMINY C}

W opracowaniu tym przedstawiono przygotowanie filmów zawierających nanocząsteczki srebra, względnie witaminę C w matrycy polimerowej, która jest w stanie wchłonąć ekstremalną ilość wody. Jako odczynniki redukujące w tym przypadku zastosowano grupy $\mathrm{COOH}$ w CMC oraz kwas askorbinowy. Przygotowane filmy z nanocząsteczkami srebra i witaminy $\mathrm{C}$ są badane przy użyciu skaningowego mikroskopu elektronowego. Ponadto badana jest ich aktywność antyutleniająca i antymikrobowa. Produkt prezentowanej technologii jest nietoksyczny, ma duży potencjał zastosowań biologicznych. 